
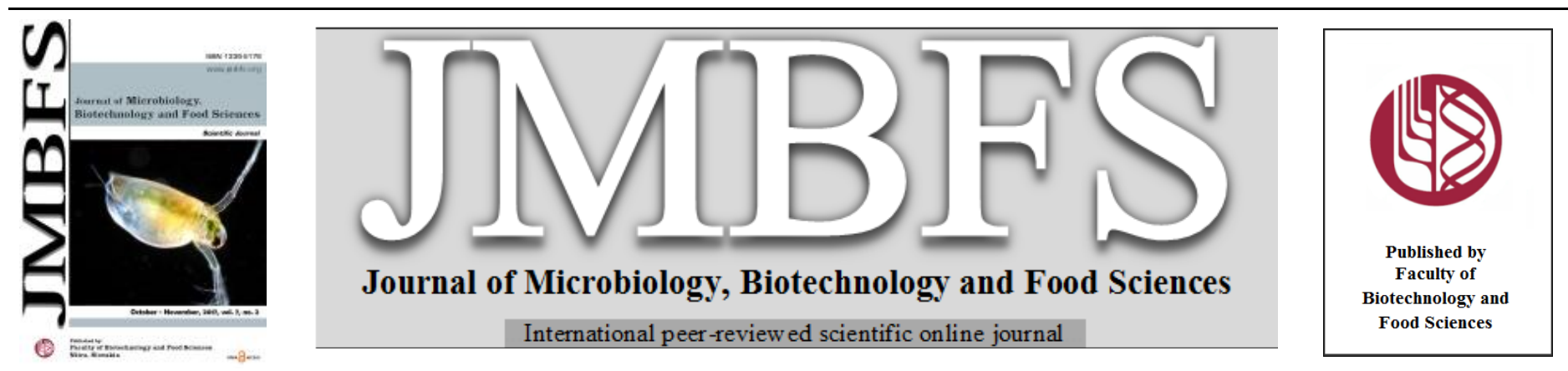

\title{
BACTERIAL BIOFILM CELLS QUANTIFICATION TECHNIQUES: WHERE IS CONSENSUS IN OVER TWO DECADES?
}

\author{
Charles Ochieng' Olwal ${ }^{*}$, Daniel Otieno Ochiel ${ }^{1}$, David Miruka Onyango ${ }^{1}$, Paul Oyieng' Ang 'ienda ${ }^{l}$
}

Address(es): Charles Ochieng' Olwal,

${ }^{1}$ Maseno University, School of Physical and Biological Sciences, Zoology Department, Kisumu-Busia Road, P.O. Box, 40105, Maseno, Kenya, Tel: +254 (035) 51622

*Corresponding author: olwalco@gmail.com

doi: 10.15414/jmbfs.2017.7.2.168-173

\section{ARTICLE INFO}

Received 15. 11. 2016

Revised 12.9. 2017

Accepted 12. 9. 2017

Published 1. 10. 2017

\section{Review}

open $\odot$ access

\begin{abstract}
It is widely accepted that bacterial biofilms are overly resistant to antibiotics, host immunity and disinfectants. Biofilms develop on various food-processing surfaces hence pose major risks in food industries. Biofilms serve as protective niches for pathogens in food and water thus enhance transmission of food borne pathogens. Furthermore, biofilms are implicated in medical implant infections. The serious problems associated with bacterial biofilms in food, biomedical and environmental fields have stimulated active research on biofilms for over two decades. Biofilm cells quantification is important in many research applications especially in anti-biofilm efficacy studies and quality controls in many industries. However, to date there is no consensus on which technique is most suitable for quantifying bacterial biofilm cells. This apparent lack of a standard technique has hindered effective comparison of results from different bacterial biofilm studies since each technique has a unique readout. Furthermore, it appears that the choice of a biofilm cells quantification technique is largely a matter of convenience and availability of a technique. This may introduce biasness. Consequently, this review critically assesses the availability, suitability and limitations of different techniques for quantifying biofilm cells. This could inform better control and management of bacterial biofilms in environmental and clinical settings.
\end{abstract}

Keywords: Biofilm quantification, CFU, Metabolic assays, FISH, NGS

\section{INTRODUCTION}

Bacterial biofilm is described as a surface-attached multi-layered community of bacteria encased in an extracellular matrix (Stewart \& Costerton, 2001) Biofilms are ubiquitous in virtually every kind of environment including plants and animals (Tan et al., 2014; Nadell et al., 2008). Bacterial biofilms have been reported to be overly resistant to many antibiotics, host immunity and disinfectants (Høiby et al., 2011). The high resistance of bacterial biofilms is thought to be due to one or a combination of mechanisms such as slow penetration of anti-biofilms across the extracellular matrix, chemical heterogeneity (existence of poor or no growth regions), adaptive stress responses and existence of few extremely resistant (persister) biofilm cells (Stewart $\boldsymbol{\&}$ Costerton, 2001). Biofilms cause disproportionate problems in food, biomedical and environmental fields (Simões et al., 2010). Biofilms thrive on most common food-processing surfaces such as plastic, glass, rubber or stainless steel (Arnold \& Bailay, 2000) hence pose major risks in food industries (Simões et al., 2010). Biofilms serve as protective niches for pathogens (Simões \& Simões, 2013) thus enhance survival and transmission of food borne pathogens (Shi \& Zhu, 2009). Consequently, disinfection of surfaces using chlorine, quaternary ammonium compounds, chloramines, hydrogen peroxide, iodine, ozone and peracetic acid has been employed widely in an attempt to eliminate bacterial biofilms from food-processing surfaces (Srey et al., 2013) albeit with little success. The disinfectants react with various components of bacterial cells to neutralize their lethal effects (Olszewska, 2013). Some of the problematic bacterial biofilms in the food industry include Salmonella spp., Pseudomonads spp., Listeria monocytogenes, Campylobacter jejuni, Escherichia coli 0517:H7, Staphylococcus spp., and Bacillus spp. (Tan et al., 2014). Annually, 9.8 million cases of food borne infections are reported in the United States alone (MMWR, 2013). The food borne infections could largely be associated with bacterial biofilms since approximately $80 \%$ of bacterial diseases are biofilm-related (NIH, 1997). In addition, bacterial biofilms are the major culprits in nosocomial infections involving medical implants (Francolini \& Donelli, 2010) such as catheters, prosthetic valves and contact lenses (Chadha, 2014). The significant public health impact of biofilms has stimulated active bacterial biofilm researches for more than two decades (Uppuluri \& Lopez-Ribot, 2016). However, to date no standard technique for quantifying bacterial biofilm cells has been adopted for biofilm studies. Since the readout differ depending on the choice of quantification technique (Stiefel et al., 2016), comparison of results from various biofilm studies are hampered. A biofilm cells quantification technique should be accurate, reproducible, cost-effective, simple and provide rapid results (Donlan, 2001). This review critically assesses the availability, suitability and limitations of various techniques for biofilm cell quantification applicable in anti-biofilm (antibiotics and disinfectants) efficacy determination and quality controls in different industries. Although the primary focus is on quantification of biofilm cells, the techniques described have other important applications in microbiology.

\section{Colony forming unit (CFU) count technique}

CFU count technique is routinely used in hospitals, food and pharmaceutical industries and microbiology laboratories for quantification of culturable microorganisms ( Lin \& Stephenson, 1998). CFU count technique is widely used to gauge the suitability of most novel biofilm cells quantification techniques (Cerca et al., 2005; Freitas et al., 2014). This is majorly because the method is highly sensitive and reliable (Cerca et al., 2005; Pan et al., 2014). Due to the wide application of CFU count method, studies have proposed ways of enhancing its sensitivity and specificity. For instance, Trampuz et al. (2007) reported that culturing of samples obtained from sonication of prostheses greatly increased sensitivity and specificity of CFU counts. This demonstrates that the CFU count technique can be improved by adopting suitable biofilm disruption techniques such as sonication. Furthermore, since biofilms exist mostly as multi-species communities (Burmølle et al., 2006; Beloin \& Ghigo, 2005), CFU count method can differentiate individual bacterial species in the biofilm community using bacterial colony characteristics such as morphology and colour (Jahid \& Ha, 2014). Nonetheless, the technique suffers many inherent limitations. First, the outcome of CFU count method is dependent on time and condition of incubation and aliquot dilution factor hence could give irreproducible results (Sutton, 2011). Secondly, in most cases optimal colonies counting range varies between 25 and 400 depending on the dilution factor of the aliquot or plate size (Ben-David \& Davidson, 2014). Thirdly, CFU count method is time consuming due to long bacterial incubation hours (Speranza et al., 2014). Fourthly, the technique is only suitable for enumerating culturable bacterial species yet over $98 \%$ of bacteria in the environment (biofilm included) are unculturable (Stewart, 
2012; Streit \& Schmitz, 2004). Moreover, most biofilm cells exist in viable but non-culturable (VBNC) state (Li et al., 2014). VBNC are living cells that have temporarily lost ability to grow on routine media (Oliver, 2000). VBNC are cells in latency state and can lead to disease recurrence (Rivers \& Steck, 2001) hence VBNC detection and enumeration is imperative. The existence of unfavourable microenvironment within the biofilm matrix or exposure to antibiotics predisposes biofilm cells to VBNC formation (Stewart \& Franklin, 2008; Pasquaroli et al., 2013). In instances where all biofilm cells transform to VBNC state or a technique fails to detect and quantify VBNC, it may be wrongly interpreted that an antibiotic has effectively eliminated all biofilm cells contaminants (Li et al., 2014) this may have detrimental health effects. The fact that CFU count technique cannot detect and quantify VBNC limits its application in quantification of most biofilm-forming bacteria. Lastly, CFU count method cannot count inactive or damaged biofilm cells (Davey, 2011) (Tab 1). To avoid underestimating cell counts by counting one colony per biofilm cluster rather than one colony per biofilm cell (Uppuluri et al., 2006), effective disruption of biofilm cells from surfaces and disintegration into individual cells is crucial (Welch et al., 2012). Dislodging biofilms from surfaces and their disintegration into single cells is mostly achieved by vortexing or sonication (Freitas et al. 2014). However, the success of vortexing or sonication is largely dependent on the type and species of a bacterium (Bjerkan et al., 2009; Monsen et al., 2009), age of biofilms (Freitas et al., 2014) and duration and intensity of vortexing or sonication (Freitas et al., 2014; Kobayashi et al., 2007). CFU is an estimate of cell counts per unit volume or area (Sutton, 2011) hence it is necessary to normalize CFU count to enable proper comparison of results obtained intra- or inter-studies. This is challenging since different CFU normalization formulae exist. For instance, $\mathrm{CFU} / \mathrm{ml}$ or $\mathrm{CFU} / \mathrm{cm}^{2}$ are directly converted into logarithm $(\log )$ of $\mathrm{CFU} / \mathrm{ml}$ or $\log$ of $\mathrm{CFU} / \mathrm{cm}^{2}$ respectively (Abdallah et al., 2014; Cerca $\boldsymbol{e}$ al., 2005; Weber et al., 2010). In some cases, $\mathrm{CFU} / \mathrm{cm}^{2}$ or $\mathrm{CFU} / \mathrm{ml}$ is converted to $\log$ of percent survival with time (Steed \& Falkinham, 2006). In one study, $\mathrm{CFU} / \mathrm{ml}$ was converted into percentage of killed or live bacteria using the formula $\left\{1-\left(\mathrm{CFU}_{\text {stress }} / \mathrm{CFU}_{\text {control }}\right) \times 100\right\}$ (Voug et al., 2004). Moreover, some studies have converted $\mathrm{CFU} / \mathrm{ml}$ or $\mathrm{CFU} / \mathrm{cm}^{2}$ into log reduction using formula, \{ $\log \left(\mathrm{cfu}_{\text {after exposure }} / \mathrm{cfu}_{\text {before exposure }}\right)$ (Anderl et al., 2000; Stewart et al., 2001; Behnke et al., 2011). Normalization formulae above give different outputs thus limiting comparison of results obtained from different CFU count technique studies.

Table 1 Summary of advantages and limitations of CFU count technique

\begin{tabular}{lll}
\hline Advantages & Limitations & References \\
\hline & & Cerca et al., 2005 \\
Sensitive & Only count culturable & Davey, 2011 \\
Reliable & bacterial species & Burmølle et al., \\
Able to differentiates & Cannot detect VBNC & 2006 \\
bacteria species in & Time consuming & Pab et al., 2014 \\
mixed-species biofilm & Irreproducibile results & Speranza et al., \\
& Small countable range & Li et al., 2014 \\
& & Sutton, 2011 \\
\hline
\end{tabular}

\section{Metabolic assays}

Two metabolic assays, colorimetric XTT and Alamar Blue (resazurin) have been used to estimate cell densities in microbial biofilm studies (Uppuluri et al., 2006). In XTT assay, three compounds namely XTT (2,3-bis (2-methoxy-4-nitro5 -sulfophenyl)-5-[(phenylamino) carbonyl]-2H-tetrazolium hydroxide) menadione and phosphate buffer saline are utilized (Silva et al., 2008). In XTT assay, the tetrazolium salt (XTT) is reduced by metabolically active cells into a coloured water-soluble formazan derivative that is quantifiable colorimetrically (Tunney et al., 2004). On the other hand, Alamar blue assay is a single step process (Pettit et al., 2009) that involves reduction of a blue dye (resazurin) by metabolically active cells into a pink metabolite (resorufin) which fluoresces (O'Brien et al., 2001). The fluorescence is directly related to bacterial biofilm cells number (Mariscal, et al., 2009). Reduction of resazurin occurs through $\mathrm{FADH}_{2}, \mathrm{NAHD}, \mathrm{NADPH}, \mathrm{FMNH}_{2}$ and cytochromes. The fluorescence data can be generated with naked eye or by means of fluorescence and absorbance techniques. Unlike the XTT assay that uses toxic menadione, Alamar blue assay has no toxic components or by-products that may affect humans or bacterial biofilm cells metabolism (Pettit et al., 2009; Bonnier et al., 2015). Moreover, Alamar Blue dye is stable hence can be incubated over long periods for example during kinetic studies involving biofilm cells (Bonnier et al., 2015). The main advantage of metabolic assays is their rapid output of results in comparison to CFU count technique (Pettit et al., 2009; Silva et al., 2008). In addition, metabolic assays require simple and inexpensive protocol (Pettit et al., 2009) Despite the above advantages, metabolic assays have certain limitations. First, correlation of metabolic activity and cell numbers is only linear in the early stages of biofilm growth (Uppuluri et al., 2006) thus; metabolic assays cannot be applied for quantification of mature biofilm cells. Secondly, a decreased resazurin reduction has been observed in the presence of antibacterials thus, reliability of Alamar Blue assay in anti-biofilm researches is not guaranteed
(Mariscal, et al., 2009). Thirdly, mature biofilms form heterogeneous structures with uneven metabolic activities and nutrient distribution (Silva et al., 2008 Rani et al., 2007). Fourthly, heterogeneity of biofilms has been demonstrated in clusters that are as small as $40 \mu \mathrm{m}$ deep (Kühl et al., 2007). This suggests that metabolic assays may underestimate cell counts in mature bacterial biofilms since only biofilm cells in the regions receiving adequate nutrients and oxygen supply will be quantified. Moreover, the quantity of metabolite produced during a metabolic assay depends on the number of bacteria thus, threshold detectable signal levels may not be reached if bacterial population is small (Welch et al., 2012) (Tab 2)

Table 2 Summary of advantages and limitations of metabolic assays

\begin{tabular}{lll}
\hline Advantages & Limitations & References \\
\hline & $\begin{array}{l}\text { Affected by type of } \\
\text { experiment }\end{array}$ & \\
Rapid results & Less sensitive relative to & Silva et al. 2008 \\
Simple & CFU method & Rani et al. 2007 \\
Inexpensive & Only applicable during & Pettit et al. 2009 \\
No highly specialised & early stages of biofilm & Cerca et al., 2005 \\
personnel required & growth & Uppuluri et al., 2006 \\
& $\begin{array}{l}\text { Underestimate cells in } \\
\text { mature biofilms }\end{array}$ & Welch et al., 2012 \\
& $\begin{array}{l}\text { Dependent on strain, type } \\
\text { and number of bacteria }\end{array}$ & \\
& & \\
\hline
\end{tabular}

\section{Flow cytometry}

Flow cytometry is a considerably reliable and rapid bacterial cell count technique in many complex environments (Monfort \& Baleux, 1992). Consequently, flow cytometry is rapidly being embraced for bacterial cells enumeration in many dairy and food microbiology processes (Díaz et al., 2010; Sohier et al., 2014). Flow cytometry technique utilizes a combination of dyes. This include a membrane-permeable dye such as SYTO 9 that stains viable and dead cells and a membrane-impermeable dye e.g. propidium iodide that stains DNA of damaged cells (Khan et al., 2010). Since a combination of dyes is costly, efforts are being made to come up with single-stain assays for bacterial biofilm studies (Kerstens et al. (2014). Flow cytometry technique has been shown to be less selective of bacterial species, does not discriminate samples based on storage or incubation period (Khan et al., 2010). In addition, flow cytometry is capable of distinguishing VBNC, dead and viable bacterial cells. Results are also produced rapidly (Lehtinen et al., 2004). However, flow cytometry has some limitations. First, extracellular DNA is the main component of extracellular matrix ( Wu $\&$ Xi, 2009) and as a result, SYTO 9 dye used stains both intracellular and extracellular DNA (Peeters et al., 2008) leading to overestimation of cell counts. Moreover, extracellular DNA staining by SYTO 9 creates confusion between hybridized cells and background signals (aberrant fluorescence) thus overestimating biofilm cell counts (Perez-Feito et al., 2006; Ambriz-Aviña et al., 2014). Secondly, for successful analysis, flow cytometry technique requires single cell monodisperse suspension (Perez-Feito et al., 2006). This could be achieved by passing biofilms through a pipette, needle or by mild sonication (Garcia-Betancur et al., 2012). In complex biofilms, dispersal of clusters into single free cell suspension is not easy, making analysis difficult (Perez-Feito et al., 2006). Moreover, mild sonication does not clear biofilm clusters effectively (Bjerkan et al., 2009; Freitas et al., 2014). Thirdly, the small sizes of bacteria biofilm cells limit their detection by flow cytometry technique (Müller \& Davey, 2009). Fourthly, flow cytometry require SYTO 9 dye that is expensive and does not stain Gram-negative bacteria properly (Stiefel et al., 2015; Stiefel $\boldsymbol{e t}$ al. 2016). Lastly, flow cytometry requires expensive equipment and highly skilled personnel to operate and interpret results (Ambriz-Aviña et al., 2014) (Tab 3).

\begin{tabular}{lll}
\multicolumn{2}{l}{ Table 3 Summary of advantages and limitations of flow cytometry technique } \\
\hline Advantages & Limitations & References \\
\hline & $\begin{array}{l}\text { Expensive equipment and } \\
\text { dye }\end{array}$ & \\
& Highly skilled personnel & \\
Less selective of & needed & Kerstens et al., \\
bacterial species & SYTO 9 is not suitable for & 2014 \\
Produce rapid results & Gram-negative bacteria & Khan et al., 2010 \\
Detect and count & Overestimate count by & Ambriz-Aviña et \\
VBNC & staining extracellular DNA & al., 2014 \\
Does not discriminate & Clusters and single cells & Stiefel et al., 2016 \\
samples based on & are indistinguishable & Müller \& Davey, \\
storage and incubation & Cannot detect small-sized & 2009 \\
duration & bacterial cells & \\
& Overestimation of count & \\
& due to aberrant & \\
& fluorescence & \\
\hline
\end{tabular}




\section{Transcriptomic approaches}

The realization that bacterial biofilms frequently undergo phenotypic and genotypic changes, revert to VBNC state and the abundance of unculturable isolates has necessitated development of transcriptomic approaches to study multi-species bacteria in food and medical environments (Trevors, 2011; Stewart, 2012; Jahid \& Ha, 2014). These approaches include Propidium monoazide quantitative (q) PCR (PMA-qPCR), qPCR without PMA and nex generation sequencing (NGS) (Sohier et al., 2014).

A combination of $\mathrm{qPCR}$ together with an intercalating agent, propidium monoazide (PMA-qPCR) has been used to quantify oral multi-species biofilms (Álvarez et $\boldsymbol{a l}$., 2013). In addition, PMA-qPCR has been used to enumerate Pseudomonas aeruginosa in multi- and mono-species biofilms exposed to antibiotics (Tavernier \& Coenye, 2015). In PMA-qPCR technique, PMA selectively penetrates damaged cell membranes and intercalates in double stranded (ds) DNA. Bacterial DNA is then isolated and quantified in a thermocycler with suitable primers. The dsDNA-PMA complex cannot be utilized as a PCR template thus membrane-damaged or dead bacterial biofilm cells are not quantified (Álvarez et al., 2013). This technique does not overestimate cell counts since PMA also intercalates extracellular DNA (Nocker et al., 2007). Nevertheless, PMA-qPCR technique has a number of limitations. First, PMA-qPCR does not quantify viable cells even if cell membrane is slightly damaged (Strauber \& Muller, 2010) hence may underestimate cell counts Secondly, quantification of cells is normally impractical when the density of dead cells exceeds $10^{4}$ cells/ml (Fittipaldi et al., 2012). Thirdly, dsDNA-PMA binding may not occur properly when other intercalating agents exist in the environment (Taylor et al., 2014) hence biofilm cells numbers may be overestimated. Lastly, PMA-qPCR technique is only limited to enumeration of biofilm cells that have been exposed to membrane-targeting anti-biofilm agents (Nocker \& Camper, 2009).

qPCR without PMA based on bacterial-specific primers is useful in distinguishing and enumerating known species from multi-species bacteria biofilms (Ren et al., 2013). qPCR technique is associated with some advantages. First, qPCR provide rapid results and offer high specificity especially in dairy industries (Boyer \& Combrisson, 2013). Secondly, since RNA is targeted in qPCR analysis, the technique distinguishes bacteria that are viable, dead or in VBNC state (Sohier et al., 2014; Falentin et al., 2010). In spite of the pros, this technique has some limitations. First, RNA has short and variable half-life and requires complex extraction process to obtain high quality RNA especially from complex biofilm matrices (Postollec et al., 2011). Secondly, qPCR is highly sensitive implying that the output is significantly affected by minor variations at the sample preparation or amplification stages (Sohier et al., 2014). Thirdly, there is no clearly agreed protocol for performing experiments and interpreting qPCR data making comparisons difficult (Bustin, 2009; Boyer and Combrisson, 2013). Like PMA-qPCR, qPCR without PMA technique also require expensive qPCR reagents, equipment and highly skilled personnel (França et al., 2012). Furthermore, challenges of sample preparation, primer design, optimization and interpretation of results also limit qPCR application (Pantanella et al., 2013).

In the recent years, next-generation sequencing (NGS) technologies have been developed and utilized in studies to understand biofilms' cellular activities, relationship between essential genes in biofilm formation and biofilm community structures (Franklin et al., 2015). NGS technologies can identify specific bacterial biofilms in clinical (Huebinger et al., 2013) and environmental samples (Jorth et al., 2014). NGS technologies offer several advantages as summarized by Grumaz et al. (2016) as follows. First, NGS technologies provide an opportunity for detecting any type of microbes in a single assay. Two, NGS technologies are quantitative methods that concurrently enumerate sequence reads and calculate statistical significance. Three, NGS technologies are unbiased and untargeted and as such utilize information from any DNA sequence resulting in higher sensitivity and specificity. Lastly, since NGS technologies are cultureindependent (Grumaz et al. 2016) they are suitable alternatives for detecting and counting wide diversity of unculturable bacterial biofilms (Douterelo et al., 2014; Metzker, 2010). However, some drawbacks are associated with NGS technologies. First, analysis of the sequence data is complex, time-consuming (Franklin et al., 2015) and requires critical competencies in bioinformatics (Barzon et al., 2011). Secondly, NGS technologies are expensive (Grumaz $\boldsymbol{e} t$ al., 2016) due to initial computing resources needed for data handling (Barzon $\boldsymbol{e t}$ al., 2011). Moreover, most NGS technologies suffer low resolutions hence cannot identify microbes to species level (Douterelo et al., 2014) (Tab 4).

Table 4 Summary of advantages and limitations of transcriptomic approaches

\begin{tabular}{|c|c|c|}
\hline Advantages & Limitations & References \\
\hline $\begin{array}{l}\text { PMA-qPCR } \\
\text { Highly selective } \\
\text { Accurate } \\
\text { Rapid results }\end{array}$ & $\begin{array}{l}\text { Expensive equipment } \\
\text { and reagents } \\
\text { Highly skilled personnel } \\
\text { required } \\
\text { Limited by number of } \\
\text { dead cells }\left(>10^{4} \text { cells/ml) }\right. \\
\text { Doesn't quantify slightly } \\
\text { damaged cells } \\
\text { dsDNA-PMA binding } \\
\text { affected by other } \\
\text { compounds in the } \\
\text { environment } \\
\text { Complex primer design, } \\
\text { optimization and sample } \\
\text { preparation } \\
\text { Only suitable for } \\
\text { counting cells with } \\
\text { damaged membranes }\end{array}$ & $\begin{array}{l}\text { Strauber \& Muller, } \\
2010 \\
\text { Nocker } \text { et al., } 2007 \\
\text { França } \text { et al., } 2012 \\
\text { Fittipaldi } \text { et al., } 2012 \\
\text { Taylor } \text { et al., } 2014 \\
\text { Pantanella } \text { et al., } 2013 \\
\text { Nocker \& Camper, } \\
2009\end{array}$ \\
\hline
\end{tabular}

qPCR (without PMA)

Distinguishes a bacterial species from mixed species biofilm

Rapid results and high specificity

Distinguishes viable, dead bacteria or VBNC state

\section{NGS technologies}

Provides functional roles

of genes in biofilm developmental stages Detects many microbial type in a single assay Concurrently enumerates sequence reads and calculates statistical significance

Higher sensitivity and specificity

Suitable alternative for detecting and counting unculturable microbes

\section{Fluorescence-based microscopy techniques}

A number of advanced fluorescence-based microscopy techniques namely confocal laser scanning microscopy (CLSM) and fluorescence microscopy in combination with automatic counting software are applied in biofilm cells quantification (Drago et al., 2016; Freitas et al., 2014) due to their superiority over the CFU count technique (Freitas et al., 2014). A report by Drago et al (2016) showed that CLSM is both simple and reliable for quantifying biofilm cells. An evaluation of fluorescence microscopy in combination with automatic counting software showed that it is precise, unaffected by person-to-person interpretation variations and distinguishes between a cell cluster and an individual cell (Freitas $\boldsymbol{e t}$ al., 2014). Nonetheless, fluorescence-based microscopy techniques have some limitations. First, a detailed optimization process is required (Hannig et al., 2010). Secondly, in analysis involving thick biofilms, one is likely to underestimate cell counts due to fluorochrome fading (Dige et al., 2007). Thirdly, the techniques utilize SYTO 9 that is expensive and does not properly stain Gram-negative bacteria (Stiefel et al., 2015). Moreover, SYTO 9 stain do not discriminate extracellular DNA thus compromises biofilm cell count (Peeters et al., 2008). Fourthly, mature biofilms form patches (heterogeneity) of cells that once spread on a microscope slide leaves only a small region of the biofilm for counting hence affects precision of cell count (Perez-Feito et al., 2006). Fifth, CLSM utilizes complex equipment that requires stringent set-up conditions to guarantee accurate signals (Pantanella et al., 2013). Lastly, fluorescence staining images may not be interpreted correctly by a substantial subset of humans who are green/red colour blind (Hope et al., 2002) (Tab 5). 
Table 5 Summary of advantages and limitations of fluorescence-based techniques

\begin{tabular}{lll}
\hline Advantages & Limitations & References \\
\hline & $\begin{array}{l}\text { Require thorough } \\
\text { optimization process }\end{array}$ & \\
& $\begin{array}{l}\text { Complex equipment with } \\
\text { stringent set-up }\end{array}$ & \\
Not affected by person- & Hannig et al., 2010 \\
to-person variations & conditions and expensive & Fazli et al., 2011 \\
High precision & dye & Freitas et al., 2014 \\
$\begin{array}{l}\text { Distinguish clusters and } \\
\text { individual cells }\end{array}$ & Underestimate counts of & Stiefel et al., 2015 \\
Simple and reliable & thick biofilms & Pantanella et al., 2013 \\
& $\begin{array}{l}\text { Not suitable for Gram- } \\
\text { negative bacteria }\end{array}$ & Perez-Feito et al., 2006 \\
& Only small biofilm & \\
& surface is exposed for & \\
& counting & \\
\hline
\end{tabular}

\section{Fluorescence in situ hybridization technique (FISH)}

FISH application in detection and enumeration of dairy microbes in cheese and yoghurt has been documented (Babot et al., 2011; García-Hernández $\boldsymbol{e t}$ al. 2012). FISH technique is a genetic method that relies on oligonucleotide probes labelled with fluorescent dyes that specifically bind to ribosomal RNA or any other specific molecule of interest (Pantanella et al., 2013). In many cases, FISH is used in combination with CLSM or epifluorescence microscopy for studying oral biofilms at various developmental stages (Dige et al., 2007; Hannig et al., 2007). One of the key strengths of FISH lies in its ability to specifically detect and provide spatial distribution of small quantities of bacterial biofilm cells clusters in food samples or human tissues (Sohier et al., 2014). Moreover, FISH can differentiate different bacterial species, detect VBNC and metabolically iner biofilm cells (Pantanella et al., 2013). However, FISH has some limitations. First, FISH has a low sensitivity since metabolically inert cells tend to have a lower cellular ribosomal content (Dongari-Bagtzoglou, 2008). However, in some bacterial species, metabolically inert cells have high cellular ribosoma content (Daims \& Wagner, 2007). This suggests that the success of FISH technique is dependent on the bacterial species. Second, the fluorescent dyes used in this technique such as SYTO 9, PI are only suitable for biofilm cells having intact membranes. This may result in underestimation of cell counts in cases where injured cells exist (Dongari-Bagtzoglou, 2008). Third, the numbers of bacterial biofilms that may be quantified are limited by the fewer oligonucleotide probes available (Hannig et al., 2010). Fourth, FISH technique is time consuming, costly and requires complex sample preparation (Fazli et al., 2011; Machado et al., 2012). Fifth, the fixation and washing steps required in FISH technique removes or alters significant portion of biofilm hence can underestimate bacterial biofilm cell count. However, a combination of FISH with CLSM can help overcome this challenge (Daims \& Wagner, 2007). However, combination of FISH and CLSM can increase the cost of biofilm quantification. Sixth, FISH provide semiquantitative data (Pantanella et al., 2013). Lastly, accurate detection of metabolically active cells requires oligonucleotide probes targeting intergenic spacer regions in ribosomal RNA genes. However, during maturation of ribosomes in bacteria, intergenic spacer regions are quickly degraded. This implies that detection and enumeration is limited only to cells producing new ribosomal RNA at a given sampling time (Daims \& Wagner, 2007) (Tab 6).

Table 6 Summary of advantages and limitations of FISH technique

\begin{tabular}{lll}
\hline Advantages & Limitations & References \\
\hline & $\begin{array}{l}\text { Few oligonucleotide } \\
\text { probes }\end{array}$ & \\
Time consuming and & Hannig et al., 2010 \\
Distinguish bacterial & expensive & Fazli et al., 2011 \\
species & Suitable for staining & Sohier et al., 2014 \\
Detect VBNC and & biofilm cells with intact & Machado et al., 2012 \\
metabolically inactive & membranes & Pantanella et al., 2013 \\
cells & Provide semiquantitative & Dongari-Bagtzoglou, \\
$\begin{array}{l}\text { Detect small quantities } \\
\text { of biofilm cells or } \\
\text { clusters }\end{array}$ & data & 2008 \\
& $\begin{array}{l}\text { Dependent on bacterial } \\
\text { species }\end{array}$ & Daims \& Wagner, \\
& FISH alone underestimate & \\
& cell counts & \\
\hline & & \\
\hline
\end{tabular}

\section{CONCLUSION AND FUTURE DIRECTIONS}

Quantification of bacterial biofilm cells is critical for a host of research and industrial applications yet challenging. It is generally agreed that a suitable technique for biofilm quantification should possess the following features: simple, accurate and inexpensive. Moreover, a technique should provide rapid and reproducible results and have negligible intra- and inter-species variations. Over the years, several techniques discussed above have been applied to quantifying biofilm cells. Each of the techniques described above have limitations hence choosing a single technique that can effectively quantify cells regardless of cell type, species or growth stage is difficult. This is posing a serious challenge especially in the progress of anti-biofilm research in which clear comparison of data from different studies is crucial. Therefore, the need for a technique that can serve as standard for quantifying biofilm cells cannot be overemphasized. It appears that flow cytometry and NGS technologies are promising and accurate techniques for quantifying bacterial biofilm cells. With an effective method that dislodges biofilms from surfaces into single free cells suspension suitable for use in flow, flow cytometry can quantify and distinguish bacterial biofilm cells irrespective of whether they have intact membranes, damaged membranes, are in VBNC state or are inactive. Moreover, with the increasing appreciation of the importance of unculturable bacterial diversity in many environmental, health and industrial settings, application of NGS technologies will be indispensable. Taken collectively, the fact that the two techniques can identify, detect and differentiate dead, VBNC, unculturable and viable bacterial cells make them suitable for many applications such as antibiofilm research, diagnostics and quality control programs. However, the key limitations of the two techniques that need to be addressed are the high initial installation cost, expensive reagents and highly skilled personnel needed to operate and interpret data. A concerted effort from different players is imperative to reduce installation costs, cost of reagents and develop more user-friendly equipment and software. Moreover, improvement of resolution of NGS technologies will enable identification of microorganisms beyond the species level. This will increase the applications NGS technologies by the biofilm research community worldwide and thus lead to tremendous progress in antibiofilm research. Moreover, this will improve detection and quantification of pathogenic bacterial biofilms from medical and food environments. Taken collectively, reduction of the limitations associated with flow cytometry and NGS technologies will greatly improve biofilm control, eradication and management in diverse environmental and clinical settings.

\section{REFERENCES}

Abdallah, M., Drider, D., \& Chihib, N. (2014). Effectives of growth temperature, surface type and incubation time on the resistance of Staphylococcus aureus biofilms to disinfectants. Appl. Microbiol. Biotech., 98, 2597-2607. http://dx.doi.org/ 10.1007/s00253-013-5479-4

Álvarez, G., Gonzalez, M., Isabal, S., Blank, V., \& Leon, R. (2013). Methods to quantify live and dead cells in multispecies oral biofilm by real-time PCR with propidium monoazide. AMB Express, 3, 1-8. http://dx.doi.org/10.1186/2191$\underline{0855-3-1}$

Ambriz-Aviña, V., Contreras-Garduño, J., \& Pedraza-Reyes, M. (2014) Applications of flow cytometry to characterize bacterial physiological responses Biomed. Res. Int., 2014, 1-14. http://dx.doi.org/10.1155/2014/461941

Anderl, J., Franklin, M., \& Stewart, P. (2000). Role of antibiotic penetration limitation in Klebsiella pneumoniae biofilm resistance to ampicillin and ciprofloxacin, Antimicrob. Agents Chemother., 44, 1818-1824. http://dx.doi.org/ 10.1128/AAC.44.7.1818-1824.2000

Arnold, W., \& Bailey, W. (2000). Surface finishes on stainless steel reduce bacterial attachment and early biofilm formation: scanning electron and atomic force microscopy study. Poultry Sci., 79, 1839-1845. http://dx.doi.org/10.1093/ps/79.12.1839

Babot, D., Hidalgo, M., Arganaraz-Martinez, E., Apella, C., \& Perez Chaia, A (2011). Fluorescence in situ hybridization for detection of classical propionibacteria with specific $16 \mathrm{~S}$ rRNA-targeted probes and its application to enumeration in Gruyere cheese. Int. J. Food Microbiol., 145, 221-228. http://dx.doi.org/10.1016/j.ijfoodmicro.2010.12.024

Barzon, L., Lavezzo, E., Militello, V., Toppo, S., \& Palù, G. (2011). Applications of next-generation sequencing technologies to diagnostic virology. Int. J. Mol. Sci., 12, 7861-7884. http://dx.doi.org/10.3390/ijms12117861

Behnke, S., Parker, A., Woodall, D., \& Camper, A. (2011). Comparing the chlorine disinfection of detached biofilm clusters with those of sessile biofilms and planktonic cells in single- and dual-species cultures. Appl. Environ. Microbiol., 77, 7176-7184. http://dx.doi.org/10.1128/AEM.05514-11

Beloin, C., \& Ghigo, M. (2005). Finding gene-expression patterns in bacterial biofilms. Trends Microbiol., 13, 16-19. http://dx.doi.org/10.1016/j.tim.2004.11.008

Ben-David, A., \& Davidson, C. (2014). Estimation methods for serial dilution experiments. J. Microbiol. Methods, 107, 214-221. http://dx.doi.org/10.1016/j.mimet.2014.08.023

Bjerkan, G., Witsø, E., \& Bergh, K. (2009). Sonication is superior to scraping for retrieval of bacteria in biofilm on titanium and steel surfaces in vitro. Acta Orthop., 80, 245-250. http://dx.doi.org/10.3109/17453670902947457

Bonnier, F. Keating, M., Wrobel, T., Majzner, K., \& Baranska, M. (2015). Cell viability assessment using the Alamar blue assay: A comparison of $2 \mathrm{D}$ and $3 \mathrm{D}$ cell culture models, Toxicol. In Vitro., 29, 124-131. http://dx.doi.org/10.1016/j.tiv.2014.09.014

Boyer, M., \& Combrisson, J. (2013). Analytical opportunities of quantitative polymerase chain reaction in dairy microbiology. Int. Dairy J., 30, 45-52 http://dx.doi.org/10.1016/i.idairyj.2012.11.008 
Burmølle, M., Webb, S., Rao, D., Hansen, H., Sørensen, J., \& Kjelleberg, S. (2006). Enhanced biofilm formation and increased resistance to antimicrobial agents and bacterial invasion are caused by synergistic interactions in multispecies biofilms. Appl. Environ. Microbiol., 72, 3916-23. http://dx.doi.org/10.1128/AEM.03022-05

Bustin, A. (2009). Why the need for qPCR publication guidelines? The case for MIQE. Methods, 50, 217-226. http://dx.doi.org/ 10.1016/j.ymeth.2009.12.006

Cerca, N., Martins, S., Cerca, F., Jefferson, K., Pier, G., Oliveira, R., \& Azeredo, J. (2005). Comparative assessment of antibiotic susceptibility of coagulasenegative staphylococci in biofilm versus planktonic culture as assessed by bacterial enumeration or rapid XTT colorimetry. J. Antimicrob. Chemother., 56 , 331-336. http://dx.doi.org/10.1093/jac/dki217

Chadha, T. (2014). Bacterial biofilms: survival mechanisms and antibiotic resistance. J. Bacteriol. Parasitol., 5, 1-4. http://dx.doi.org/10.4172/2155 9597.1000190

Daims, H, \& Wagner, M. (2007). Quantification of uncultured microorganisms by fluorescence microscopy and digital image analysis. Appl. Microbiol. Biotechnol., 75, 237-248. http://dx.doi.org/10.1007/s00253-007-0886-z

Davey, M. (2011). Life, death, and in-between: meanings and methods in microbiology. Appl. Environ. Microbiol., 77, 5571-5576. http://dx.doi.org/10.1128/AEM.00744-11

Díaz, M., Herrero, M., García, A., and Quirós, C. (2010). Application of flow cytometry to industrial microbial bioprocesses. Biochem. Eng. J., 48, 385-407. http://dx.doi.org/10.1016/j.bej.2009.07.013

Dige, I., Nilsson, H., Kilian, M., \& Nyvad, B. (2007). In situ identification of streptococci and other bacteria in initial dental biofilm by confocal laser scanning microscopy and fluorescence in situ hybridization. Eur. J. Oral Sci., 115, 459467. http://dx.doi.org/10.1111/j.1600-0722.2007.00494.x

Dongari-Bagtzoglou, A. (2008). Pathogenesis of mucosal biofilm infections: challenges and progress. Expert Rev. Anti Infect. Ther., 6, 201-208. http://dx.doi.org/10.1586/14787210.6.2.201

Donlan, R. (2001). Biofilm formation: a clinically relevant microbiological process. Clin. Infect. Dis., 33, 1387-1389. http://dx.doi.org/10.1086/322972

Douterelo, I., Boxall, J., Deines, P., Sekar, R., Fish, K., \& Biggs, C. (2014) Methodological approaches for studying the microbial ecology of drinking wate distribution systems. Water Research, 65, 134-156. http://dx.doi.org/10.1016/j.watres.2014.07.008

Drago, L., Agrappi, S., Bortolin, M., Toscano, M., Romanò, C., \& De Vecchi, E. (2016). How to study biofilms after microbial colonization of materials used in orthopaedic implants. Int. J. Mol. Sci., $17, \quad$ 1-10. http://dx.doi.org/10.3390/ijms17030293

Falentin, H., Postollec, F., Parayre, S., Henaff, N., Le Bivic, P., Richoux, R., Thierry, A., \& Sohier, D. (2010). Specific metabolic activity of ripening bacteria quantified by real-time reverse transcription PCR throughout emmental cheese manufacture. Int. J. Food Microbiol., $144, \quad$ 10-19. http://dx.doi.org/10.1016/j.ijfoodmicro.2010.06.003

Fazli, M., Bjarnsholt, T., Kirketerp-Møller, K., \& Tolker-Nielsen, T. (2011) Quantitative analysis of the cellular inflammatory response against biofilm bacteria in chronic wounds. Wound Repair Regen., 19, 387- 391 http://dx.doi.org/10.1111/j.1524-475X.2011.00681.x

Fittipaldi, M., Nocker, A., \& Codony, F. (2012). Progress in understanding preferential detection of live cells using viability dyes in combination with DNA $\begin{array}{lllll}\text { amplification. } & J & \text { Microbiol. } & \text { Methods, } & \text { 91, 276-289. }\end{array}$ http://dx.doi.org/10.1016/j.mimet.2012.08.007

França, A., Freitas, A., Henriques, A., \& Cerca, N. (2012) Optimizing a qPCR gene expression quantification assay for Staphylococcus epidermidis biofilms: a comparison between commercial kits and a customized protocol, PLoS ONE, 7 , 1-9. http://dx.doi.org/10.1371/journal.pone.0037480

Francolini, I., \& Donelli, G. (2010). Prevention and control of biofilm-based medical-device-related infections. FEMS Immunol. Med. Microbiol., 59, $227-$ 238. http://dx.doi.org/10.1111/j.1574-695X.2010.00665.x

Franklin, M., Chang, C., Akiyama, T., \& Bothner, B. (2015). New technologies for studying biofilms. Microbiol Spectr., 3 , http://dx.doi.org/10.1128/microbiolspec.MB-0016-2014

Freitas, A., Vasconcelos, C., Vilanova, M., \& Cerca, N. (2014). Optimization of an automatic counting system for the quantification of Staphylococcus epidermidis cells in biofilms. J. Basic Microbiol., 54, 750-757. http://dx.doi.org/ 10.1002/jobm.201200603

Garcia-Betancur, J., Yepes, A., Schneider, J., \& Lopez, D. (2012). Single-cel analysis of Bacillus subtilis biofilms using fluorescence microscopy and flow cytometry, Journal of Visualized Experiments, 60. http://dx.doi.org/10.3791/3796 Garcia-Hernandez, J., Moreno, Y., Amorocho, M., \& Hernandez, M. (2012). A combination of direct viable count and fluorescence in situ hybridization for specific enumeration of viable Lactobacillus delbrueckii subsp. bulgaricus and Streptococcus thermophilus. Lett. Appl. Microbiol., 54, 247-254. http://dx.doi.org/10.1111/j.1472-765X.2011.03201.x

Grumaz, S., Stevens, P., Grumaz, C., Decker, S., Weigand, M., Hofer, S. Brenner, T., Haeseler, A., \& Sohn, K. (2016). Next-generation sequencing diagnostics of bacteremia in septic patients. Genome Medicine, 8, 1-13 http://dx.doi.org/10.1186/s13073-016-0326-8
Hannig, C., Follo, M., Hellwig, E., \& Al-Ahmad, A. (2010). Visualization of adherent micro-organisms using different techniques. J. Med. Microbiol., 59, $1-$ 7. http://dx.doi.org/10.1099/jmm.0.015420-0

Hannig, C., Hannig, M., Rehmer, O., Braun, G., Hellwig, E., \& Al-Ahmad, A (2007). Fluorescence microscopic visualization and quantification of initial bacterial colonization on enamel in situ. Arch. Oral Biol., 52, 1048-1056. http://dx.doi.org/10.1016/i.archoralbio.2007.05.006

Høiby, N., Ciofu, O., Johansen, H., Song, Z., Moser, C., Jensen, P., Molin, S. Givskov, M., Tolker-Nielsen, T., Bjarnsholt, T. (2011). The clinical impact of bacterial biofilms. Int. J. Oral Sci., 3, 55-65. http://dx.doi.org/10.4248/IJOS11026

Hope, K., Clements, D., \& Wilson, M. (2002). Determining the spatia distribution of viable and nonviable bacteria in hydrated microcosm dental plaques by viability profiling. J. Appl. Microbiol., 93, 448-455 http://dx.doi.org/10.1046/j.1365-2672.2002.01703.x

Huebinger, R., Liu, M., Dowd, S., Rivera-Chavez, F., Boynton, J., Carey, C. Hawkins, K., Minshall, C., Wolf, S., Minei, J., \& Barber, R. (2013). Examination with next-generation sequencing technology of the bacterial microbiota in bronchoalveolar lavage samples after traumatic injury. Surgical Infections, 14 271-281. http://dx.doi.org/10.1089/sur.2012.095

Jahid, I., \& Ha, S. (2014). The paradox of mixed-species biofilms in the contex of food safety. Comprehensive Reviews in Food Science and Food Safety, 13, 990-1011. http://dx.doi.org/10.1111/1541-4337.12087

Jorth, P., Turner, H., Gumus, P., Nizam, N., Buduneli, N., \& Whiteley, M. (2014). Metatranscriptomics of the human oral microbiome during health and disease. MBio, 5, 01012-01014. http://dx.doi.org/10.1128/mBio.01012-14

Kerstens, M., Boulet, G., Tritsmans, C., Horemans, T., Hellings, M., Delputte, P., Maes, L., \& Cos, P. (2014). Flow cytometric enumeration of bacteria using TOPRO ${ }^{-3}$-3 iodide as a single-stain viability dye. J. Lab. Autom., 19, 555-561. http://dx.doi.org/10.1177/2211068214546745

Khan, M., Pyle, B., \& Camper, A. (2010). Specific and rapid enumeration of viable but noncultuable and viable-culturable Gram-negative bacteria by using flow cytometry. Appl. Environ. Microbiol., 76, 5088-5096. http://dx.doi.org/10.1128/AEM.02932-09

Kobayashi, N., Bauer, W., Tuohy, J., Fujishiro, T., \& Procop, G. (2007). Brief ultrasonication improves detection of biofilm-formative bacteria around a metal implant. Clin. Orthop. Relat. Res., 457, 210-213. http://dx.doi.org/10.1097/blo.0b013e3180312042

Kühl, M., Rickelt, F., \& Thar, R. (2007). Combined imaging of bacteria and oxygen in biofilms. Appl. Environ. Microbiol., 73, 6289-6295. http://dx.doi.org/10.1128/AEM.01574-07

Lehtinen, J., Nuutila, J., \& Lilius, M. (2004). Green fluorescent proteinpropidium iodide (GFP-PI) based assay for flow cytometric measurement of bacterial viability. Cytometry $A, \quad 60 A, \quad 165-172$ http://dx.doi.org/10.1002/cyto.a.20026

Li, L., Mendis, N., Trigui, H., Oliver, D., \& Faucher, P. (2014). The importance of the viable but non-culturable state in human bacterial pathogens. Front. Microbiol., 5, 1-20. http://dx.doi.org/10.3389/fmicb.2014.00258

Lin, J., \& Stephenson, R. (1998). Validating an assay of viral contamination. In Peck, R., Haugh, D., \& Goodman, A. (Eds.), Statistical case studies: a collaboration between academe and industry. Philadelphia, PA: SIAM.

Machado, C., Cesar, E., Assis, V., Diniz, G., \& Ribeiro, A. (2012). Detection and enumeration of periodontopathogenic bacteria in subgingival biofilm of pregnant women. Braz. Oral Res., 26, 443-449. http://dx.doi.org/10.1590/S1806 83242012000500011

Mariscal, A., Lopez-Gigosos, M., Carnero-Varo, M., \& Fernandez-Crehuet, J (2009). Fluorescent assay based on resazurin for detection of activity of disinfectants against bacterial biofilm. Appl. Microbiol. Biotechnol., 82, 773-783. http://dx.doi.org/10.1007/s00253-009-1879-x

Metzker, I. (2010). Sequencing technologies - the next generation. Nat. Rev Genet., 11, 31-46. http://dx.doi.org/10.1038/nrg2626

Monfort, P., \& Baleux, B. (1992). Comparison of flow cytometry and epifluorescence microscopy for counting bacteria in aquatic ecosystems Cytometry, 13, 188-192. http://dx.doi.org/10.1002/cyto.990130213

Monsen, T., LÃvgren, E., WiderstrÃm, M., \& Wallinder, L. (2009). In vitro effect of ultrasound on bacteria and suggested protocol for sonication and diagnosis of prosthetic infections. J. Clin. Microbiol., 47, 2496-2501. http://dx.doi.org/10.1128/JMC.02316-08

Morbidity and Mortality Weekly Report (MMWR). (2013). Surveillance for foodborne disease outbreaks — United States, 1998-2008. Retrieved from http://www.cdc.gov/mmwr/preview/mmwrhtml/ss6202a1.htm.

Müller, S., \& Davey, H. (2009). "Recent advances in the analysis of individual microbial cells," Cytometry A, 75, 83-85. http://dx.doi.org/10.1002/cyto.a.20702 Nadell, C., Xavier, J., \& Foster, K. (2009). The sociobiology of biofilms. FEMS Microbiol. Rev., 33, 206-224. http://dx.doi.org/10.1111/j.1574 6976.2008.00150.x

National Institutes of Health (NIH). (1997). Minutes of the National Advisory Dental and Craniofacial Research Council-153rd Meeting, Bethesda, MD

Nocker, A., \& Camper, K. (2009). Novel approaches toward preferential detection of viable cells using nucleic acid amplification techniques. FEMS 

6968.2008.01429x

Nocker, A., Sossa, E., \& Camper, K. (2007). Molecular monitoring of disinfection efficacy using propidium monoazide in combination with quantitative PCR. J. Microbiol. Methods, 70, 252-260. http://dx.doi.org/10.1016/j.mimet.2007.04.014

O'Brien, J., Wilson, I., Orton, T., \& Pognan, F. (2000). Investigation of the alamar blue (resazurin) fluorescent dye for the assessment of mammalian cell cytotoxicity. Toxicol., 164, 132-132. http://dx.doi.org/10.1046/j.14321327.2000.01606.x

Oliver, D. (2000). The public health significance of viable but nonculturable bacteria. In R. Colwell \& D. Grimes (Eds.), Nonculturable microorganisms in the environment (pp. 277-300). Washington, DC: ASM press.

Olszewska, M. (2013). Microscopic findings for the study of biofilms in food environments. Acta Biochim. Pol., 60, 531-537.

Pan, H., Zhang, Y., He, G., Katagori, N., \& Chen, H. (2014). A comparison of conventional methods for the quantification of bacterial cells after exposure to metal oxide nanoparticles. BMC Microbiol., 14, 1-11. http://dx.doi.org/10.1186/s12866-014-0222-6

Pantanella, F., Valenti, P., Natalizi, T., Passeri, D., \& Berlutti, F. (2013) Analytical techniques to study microbial biofilm on abiotic surfaces: pros and cons of the main techniques currently in use. Ann. Ig., 25, 31-42. http://dx.doi.org/10.7416/ai.2013.1904

Pasquaroli, S., Zandri, G., Vignaroli, C., Vuotto, C., Donelli, G., \& Biavasco, F. (2013). Antibiotic pressure can induce the viable but non-culturable state in Staphylococcus aureus growing in biofilms. J. Antimicrob. Chemother., 68 , 1812-1817. http://dx.doi.org/10.1093/jac/dkt086

Peeters, E., Nelis, J., \& Coenye, T. (2008). Comparison of multiple methods for quantification of microbial biofilms grown in microtiter plates. J. Microbiol. Methods, 72, 157-165. http://dx.doi.org/10.1016/j.mimet.2007.11.010

Perez-Feito, R., Peccia, J., \& Noguera, D. (2006). Comparison between direct microscopy and flow cytometry for rRNA-based quantification of Candidatus accumulibacter phosphatis in activated sludge. Water Environment Research, 78, 181-188. http://dx.doi.org/10.2175/106143005X89634

Pettit, R., Weber, C., \& Pettit, G. (2009). Application of a high throughput alamar blue biofilm sucseptibility assay to Staphylococcus aureus. Annals Clin. Microbiol. Antimicrob. , 8, 1-7. http://dx.doi.org/10.1186/1476-0711-B-28

Postollec, F., Falentin, H., Pavan, S., Combrisson, J., \& Sohier, D. (2011). Recent advances in quantitative PCR (qPCR) applications in food microbiology. Food Microbiol, 28, 848-861. http://dx.doi.org/10.1016/i.fm.2011.02.008

Rani, A., Pitts, B., Veluchamy, R., Lewandowski, Z., Davison, M., BuckinghamMeyer, W., \& Stewart, P. (2007). Spatial patterns of DNA replication, protein synthesis, and oxygen concentration within bacterial biofilms reveal diverse $\begin{array}{llllll}\text { physiological states. } & J . & \text { Bacteriol., } & 189, & 4223-4233\end{array}$ http://dx.doi.org/10.1128/JB.00107-07

Ren, D., Madsen, S., Cruz-Perera, I., Bergmark, L., Sørensen, J., Burmølle, M (2013). High-throughput screening of multispecies biofilm formation and quantitative PCR-based assessment of individual species proportions, useful for exploring interspecific bacterial interactions. Microb. Ecol, http://dx.doi.org/10.1007/s00248-013-0315-z

Rivers, B., \& Steck, R. (2001). Viable but nonculturable uropathogenic bacteria are present in the mouse urinary tract following urinary tract infection and antibiotic therapy. Urol. $\quad$ Res., 29, 60-66. http://dx.doi.org/10.1007/s002400000151

Shi, X., \& Zhu, X. (2009). Biofilm formation and food safety in food industries. Trends Food Sci. Tech., 20, 407-413. http://dx.doi.org/10.1016/j.tifs.2009.01.054 Silva, W., Seneviratne, J., Parahitiyawa, N., Rosa, E., Samaranayake, L., \& Del bel Cury, A. (2008). Improvement of XTT assay performance for studies involving Candida albicans biofilms. Braz. Dent. J., 19, 364-369. http://dx.doi.org/10.1590/S0103-64402008000400014

Simões, L., \& Simões, M. (2013). Biofilms in drinking water: problems and solutions. RSC Adv., 3, 2520-2533. http://dx.doi.org/10.1039/c2ra22243d

Simões, M., Simões, L., \& Viera, M. (2010). A review of current and emergent biofilm control strategies. LWT-Food Sci. Technol., 43, 573-583. http://dx.doi.org/10.1016/j.lwt.2009.12.008

Sohier, D., Pavan, S., Riou, A., Combrisson, J., \& Postollec, F. (2014). Evolution of microbiological analytical methods for dairy industry needs. Front. Microbiol., 5, 1-10. http://dx.doi.org/10.3389/fmicb.2014.00016

Speranza, B., Racioppo, A., Bevilacqua, A., Sinigaglia, M. \& Altieri, C. (2014). Comparison of direct microbial count procedures for planktonics and sessiles enumeration. Food Nutr. Sci., 5, 2033-2037. http://dx.doi.org/10.4236/fns.2014.521214

Srey, S., Jahid, K., \& Ha, S-D. (2013). Biofilm formation in food industries: a food safety concern. Food Control, 31, 572-585. http://dx.doi.org/10.1016/j.foodcont.2012.12.001

Steed, K., \& Falkinham III, J. (2006) Effect of growth in biofilms on chlorine susceptibility of Mycobacterium avium and Mycobacterium intracellulare, Appl. Environ. Microbiol., 72, 4007-4011. http://dx.doi.org/10.1128/AEM.02573-05 Stewart, E. (2012). Growing unculturable bacteria. J. Bacteriol., 194, 4151-4160. http://dx.doi.org/10.1128/JB.00345-12
Stewart, P., \& Costerton, J. (2001). Antibiotic resistance of bacteria in biofilms. Lancet, 358, 135-138. http://dx.doi.org/10.1016/S0140-6736(01)05321-1

Stewart, P., \& Franklin, J. (2008). Physiological heterogeneity in biofilms. Nat. Rev. Microbiol., 6, 199-210. http://dx.doi.org/10.1038/nrmicro1838

Stewart, P., Rayner, J., Roe, F., \& Rees, W. (2001). Biofilm penetration and disinfection efficacy of alkaline hypochlorite and chlorosulfamates. J. Appl. Microbiol., 91, 525-532. http://dx.doi.org/10.1046/j.1365-2672.2001.01413.x

Stiefel, P., Rosenberg, U., Schneider, J., Mauerhofer, S., Maniura, K., \& Ren, Q. (2016). Is biofilm removal properly assessed? Comparison of different quantification methods in a 96-well plate system. Appl. Microbiol. Biotechnol., 100, 4135-4145. http://dx.doi.org/10.1007/s00253-016-7396-9

Stiefel, P., Schmidt-Emrich, S., Maniura K., \& Ren, Q. (2015). Critical aspects of using bacterial cell viability assays with the fluorophores SYTO9 and propidium iodide. BMC Microbiol., 15, 36. http://dx.doi.org/10.1186/s12866-015-0376-x Strauber, H., \& Muller, S. (2010). Viability states of bacteria-specific mechanisms of selected probes. Cytometry A, 77A, 623-634. http://dx.doi.org/10.1002/cyto.a.20920

Streit, W., \& Schmitz, R. (2004). Metagenomics - the key to the uncultured microbes. Curr. Opin. Microbiol., 7, 492-498. http://dx.doi.org/10.1016/i.mib.2004.08.002

Sutton, S. (2011). Accuracy of plate counts. J. Validation Technol., 17, 46-49. Tan, S., Chew, S., Tan, S., Givskov, M., \& Yang, L. (2014). Emerging frontiers in detection and control of bacterial biofilms. Curr. Opin. Biotech, 26, 1-6. http://dx.doi.org/10.1016/j.copbio.2013.08.002

Tavernier, S., \& Coenye, T. (2015). Quantification of Pseudomonas aeruginosa in multispecies biofilms. PeerJ, 3, 1-15. http://dx.doi.org/10.7717/peerj.787

Taylor, J., Bentham, H., \& Ross, E. (2014). Limitations of using propidium monoazide with qPCR to discriminate between live and dead legionella in biofilm samples. Microbiology Insights, 7, 15-24. http://dx.doi.org/10.4137/MBLS17723

Trampuz, A., Piper, K., Jacobson, M., Hanssen, A., Unni, K., Osmon, D., Mandrekar, J., Cockerill, F., Steckelberg, J., Greenleaf, J., \& Patel, R. (2007). Sonication of removed hip and knee prostheses for diagnosis of infection. $N$. Engl. J. Med., 357, 654-663. http://dx.doi.org/10.1056/NEJMoa061588

Trevors, T. (2011). Viable but non-culturable (VBNC) bacteria: gene expression in planktonic and biofilm cells. J. Microbiol. Methods, 86, 266-73. http://dx.doi.org/10.1016/j.mimet.2011.04.018

Tunney, M., Ramage, G., Field, T., Moriarty, T., \& Storey, D. (2004). Rapid colorimetric assay for antimicrobial susceptibility testing of Pseudomonas aeruginosa. Antimicrob. Agents Chemother., 48, 1879-1881. http://dx.doi.org/10.1128/AAC.48.5.1879-1881.2004

Uppuluri, P., \& Lopez-Ribot, J. (2016). Go forth and colonize: dispersal from clinically important microbial biofilms. PLoS Pathog., $12,1-9$. http://dx.doi.org/10.1371/journal.ppat.1005397

Uppuluri, P., Sarmah, B., \& Chaffin, L. (2006). Candida albicans SNO1 and SNZ1 expressed in stationary-phase planktonic yeast cells and base of biofilm. Microbiology, 152, 2031-2038. http://dx.doi.org/10.1099/mic.0.2874-0

Vuong, C., Voyich, J., Fischer, E., Braughton, K., Whitney, A., DeLeo, F., \& Otto, M. (2004). Polysaccharide intercellular adhesin (PIA) protects Staphylococcus epidermidis against major components of the human innate immune system. Cell. Microbiol. 6, 269-275. http://dx.doi.org/10.1111/j.14625822.2004.00367.x

Weber, M., French, C., Barnes, M., Siegele, D., \& McLean, R. (2010). A previously uncharacterized gene, yjfO (bsmA), influences Escherichia coli biofilm formation and stress response. Microbiology, 156, 139-147. http://dx.doi.org/10.1099/mic.0.031468-0

Welch, K., \& Cai, Y., and Strømme, M. (2012). A method for quantitative determination of biofilm viability. J. Funct. Biomater., 3, 418-431. http://dx.doi.org/10.3390/jfb3020418

Wu, J., \& Xi, C. (2009). Evaluation of different methods for extracting extracellular DNA from the biofilm matrix. Appl. Environ. Microbiol., 75, 53905395. http://dx.doi.org/10.1128/AEM.00400-09 